\title{
MENINGKATKAN KECERDASAN KINESTETIK MELALUI PEMBELAJARAN SENI PENCAK SILAT
}

\author{
Improving Kinesthetic Intelligence By Martial Arts Learning \\ Rizki Dwidana, I Gusti Komang Aryaprastya Agus ${ }^{1}$, Asep Deni Gustiana ${ }^{2}$ \\ Program Studi Pendidikan Guru Pendidikan Anak Usia Dini, Departemen Pedagogik, \\ Fakultas Ilmu Pendidikan, Universitas Pendidikan Indonesia \\ Email :dwidrizki@hotmail.com
}

\begin{abstract}
Abstrak : Pelaksanaan pembelajaran di PAUD GAMUS Bandung lebih didominasi dengan metode konvensional yang mengakibatkan anak kurang aktif dalam bergerak. Maka tujuan dari penelitian ini adalah untuk mengetahui kondisi objektif kecerdasan kinestetik anak, mendeskripsikan pelaksanaan pembelajaran seni pencak silat dan untuk mengetahui peningkatan kecerdasan kinestetik anak setelah dilaksanakan pembelajaran tersebut. Metode penelitian yang digunakan adalah penelitian tindakan kelas (PTK) pada 18 anak di PAUD GAMUS Bandung. Desain pembelajaran seni pencak silat yang digunakan mengacu pada desain pembelajaran seni tari untuk anak usia dini meliputi (a) tujuan; (b) materi pembelajaran; (c) metode; (d) sarana dan prasarana; (e) proses pembelajaran; dan (f) evaluasi telah tercapai pada setiap siklus. Pada pra siklus, terdapat 14 anak $(77,78 \%)$ yang memiliki kecerdasan kinestetik pada kategori kurang, 4 anak $(22,22 \%)$ pada kategori cukup dan 0 anak $(0,00 \%)$ pada kategori baik. Pada akhir siklus, terdapat 0 anak $(0,00 \%)$ yang memiliki kecerdasan kinestetik pada kategori kurang, 3 anak (16,67\%) pada kategori cukup dan 14 anak (83,33\%) pada kategori baik. Kesimpulan dari hasil penelitian ini adalah pembelajaran seni pencak silat dapat meningkatkan kecerdasan kinestetik anak.
\end{abstract}

Kata kunci : penelitian tindakan kelas, pembelajaran seni pencak silat, kecerdasan

\section{kinestetik.}

Abstract : The learning method in PAUD GAMUS Bandung mostly dominated
by conventional method and caused the children are less active in motion.
Beside of that the purpose of this research is to know the objective conditions
of children kinesthetic intelligence, describe the learning method of martial
arts and to know the improvement of children kinesthetic intelligence after the
learning is implemented. The method of this research is Classroom Action
Research (CAR) on 18 children in PAUD GAMUS Bandung. The design of
martial arts learning that is used refers to the design of dance learning for
early childhood include (a) the purpose; (b) learning materials; $(c)$ methods;
(d) facilities and infrastructure; (e) learning process; and $(f)$ evaluation had
been reached on every cycle. In the pre cycle, there were 14 children $(77,78 \%)$
who had kinesthetic intelligence in less category, 4 children $(22,22 \%)$ in

${ }^{1}$ Penulis Penanggung Jawab

${ }^{2}$ Penulis Penanggung Jawab 
enough category and 0 children $(0,00 \%)$ in good category. At the end of the cycle, there were 0 children $(0,00 \%)$ who had kinesthetic intelligence in less category, 3 children $(16,67 \%)$ in enough category and 14 children $(83,33 \%)$ in good category. The conclusion of this research is the learning of martial art can improve children kinesthetic intelligence.

Keyword : classroom action research, martial arts learning, kinesthetic intelligence.

\section{PENDAHULUAN}

Usia dini (0-6 tahun) merupakan masa perkembangan dengan pertumbuhan yang sangat menentukan bagi anak di masa depannya atau disebut juga masa keemasan (the golden age) sekaligus periode yang sangat kritis yang menentukan tahap pertumbuhan dan perkembangan anak selanjutnya (Suyadi, 2013, hlm.2), sehingga usia dini merupakan usia fundamental bagi perkembangan masa selanjutnya. Masa ini merupakan masa yang tepat untuk meletakkan dasar-dasar pengembangan kemampuan fisik, bahasa, sosial, emosional, seni, moral dan nilai-nilai agama. Sehingga upaya pengembangan seluruh potensi anak usia dini harus dimulai agar pertumbuhan dan perkembangan anak tercapai secara optimal. Menyadari betapa pentingnya usia dini bagi pertumbuhan dan perkembangan anak maka dilakukan pembinaan berupa Pendidikan Anak Usia Dini (PAUD).

PAUD menurut Bredekamp dan Copple (Suyadi, 2013 hlm.18) mencakup berbagai program yang melayani anak dari lahir sampai usia delapan tahun yang dirancang untuk meningkatkan perkembangan intelektual, sosial, emosi, bahasa dan fisik anak. Secara institusional Pendidikan Anak Usia Dini diartikan sebagai salah satu bentuk penyelenggaraan pendidikan yang menitikberatkan pada peletakan dasar ke arah pertumbuhan dan perkembangan, baik koordinasi motorik (halus dan kasar), kecerdasan emosi, kecerdasan

\footnotetext{
${ }^{1}$ Penulis Penanggung Jawab

2 Penulis Penanggung Jawab
}

jamak (multiple intelligences) maupun kecerdasan spiritual.

Bainbridge dalam Yaumi dan Ibrahim (2013, hlm. 9) mengatakan bahwa, "Kecerdasan sering didefinisikan sebagai kemampuan mental umum untuk belajar dan menerapkan pengetahuan dalam manipulasi lingkungan, serta kemampuan untuk berfikir abstrak", sehingga kecerdasan sering dikaitkan dengan kemampuan mengadaptasi dengan lingkungan atau keadaan baru. Beberapa jenis kecerdasan yang ditemukan oleh Gardner dalam Yaumi dan Ibrahim (2013, hlm.11) ialah kecerdasan verbal-linguistik, logismatematik, visual-spasial, beriramamusik, jasmaniah-kinestetik, interpersonal, intrapersonal, dan naturalistik, tetapi dalam penerapan di Indonesia ditambahkan menjadi sembilan kecerdasan yaitu kecerdasan spiritual. Amstrong dalam Sujiono (2010, hlm.59) mengungkapkan bahwa kecerdasan kinestetik atau kecerdasan fisik adalah suatu kecerdasan dimana saat menggunakannya seseorang mampu atau terampil menggunakan anggota tubuhnya untuk gerakan berlari, menari, membangun sesuatu, melakukan kegiatan seni dan hasta karya.

Adapun permasalahan kecerdasan kinestetik yang peneliti temukan pada saat observasi tanggal 2 Mei 2016 di PAUD GAMUS Bandung, terlihat saat anak membuat gerakan tarian, anak terlihat kesulitan berimprovisasi dalam membuat gerakan sehingga saat diberikan lagu anak hanya diam. Selain itu, anak 
masih terlihat canggung dalam bergerak, malu-malu dan tidak percaya diri dalam menggerakkan tubuhnya. Demikian pula pada observasi tanggal 11 Mei 2016 peneliti menemukan permasalahan terkait kecerdasan kinestetik, yakni saat kegiatan menari, gerakan yang dilakukan anak tidak sesuai dengan yang dicontohkan oleh guru. Selain itu, anak masih kurang dalam mengembangkan gerak tubuh melalui nyanyian, menselaraskan antara pikiran dan tubuh (koordinasi tubuh), mengembangkan kelincahan, kekuatan dan keseimbangan tubuh serta mengkoordinasi mata dengan tangan dan kaki.

Permasalahan yang ditemukan peneliti terkait kecerdasan kinestetik anak di PAUD GAMUS Bandung disebabkan oleh beberapa hal, seperti kurangnya kegiatan yang berhubungan dengan gerak, sehingga anak kesulitan dalam membuat gerakan teratur seperti menari, berolahraga dan sebagainya. Anak juga mengalami kesulitan dalam berimprovisasi dengan menciptakan gerakan. Faktor terseut diperkuat oleh pernyataan Aryaprastya (2015, hlm. 1321) yang mengungkapkan bahwa pendidik anak usia dini pada umumnya lebih suka melakukan kegiatan pembelajaran yang memfokuskan kegiatannya pada pengembangan kecerdasan linguistik dan kecerdasan logika. Oleh karena itu, diperlukan stimulasi untuk meningkatkan kecerdasan kinestetik anak di PAUD GAMUS Bandung. Dalam hal ini, peneliti akan mengaplikasikan seni pencak silat untuk mengatasi permasalahan tersebut.

Seni pencak silat (Maryono, 2000, hlm.9) merupakan wujud kebudayaan dalam bentuk kaidah gerak dan irama, yang takluk pada keselarasan, keseimbangan, dan keserasian antara wiraga, wirama dan wirasa. Seni pencak silat terdiri dari berbagai gerakan seperti memukul, menendang, merunduk, melompat, menghindar, berputar, berlatih keseimbangan dan lainnya, dimana gerakan-gerakan tersebut dapat melatih motorik anak menjadi lebih kuat, cekatan, cepat dan tangkas (Natassia dkk, 2015, hlm.2). Lebih lanjut, Natassia dkk menyebutkan manfaat mengikui pembelajaran seni pencak silat bagi anak-anak selain untuk b/ermain, membela diri mereka, dan melatih motorik, pencak silat juga dapat menjadikan anak lebih bugar dan sehat, melatih keberanian anak, meningkatkan kedisiplinan dan komitmen, serta meningkatkan kemampuan bersosialisai anak. Selain itu, gerakan pada seni pencak silat yang lebih terbuka, distilasi dan dilakukan dengan irama yang metrikal (Saleh dalam Maryono, 2000). Pada dasarnya, seni pencak silat sudah dimiliki seseorang sejak lahir seperti bayi yang biasa menendang-nendangkan kakinya atau memukul-mukulkan tangannya. Tidaklah salah bila pembelajaran pencak silat disampaikan pada anak usia prasekolah karena dapat menunjang perkembangan motoriknya (Kriswantoyo, 2008, hlm.71). Berdasarkan uraian di atas, maka peneliti terdorong untuk melakukan penelitian yang berjudul "Meningkatkan Kecerdasan Kinestetik Melalui Pembelajaran Seni Pencak Silat".

Tujuan penelitian ini yaitu : (1) mengetahui kondisi objektif kecerdasan kinestetik anak di PAUD GAMUS Bandung, (2) mengetahui pelaksanaan peningkatan kecerdasan kinestetik anak melalui pembelajaran seni pencak silat di PAUD GAMUS Bandung dan (3) mengetahui peningkatan kecerdasan kinestetik anak setelah dilaksanakan pembelajaran seni pencak silat di PAUD GAMUS Bandung.

\section{METODE}

Metode penelitian yang digunakan adalah Penelitian Tindakan Kelas (PTK) model Kemmis dan Taggart, yang dilakukan sebanyak dua siklus dengan masing-masing siklus terdiri dari dua 
tindakan. Penelitian ini dilakukan di PAUD GAMUS Bandung. Sampel yang digunakan pada penelitian ini adalah anak TK B tahun ajaran 2016-2017 yang berjumlah 18 anak. Obyek pada penelitian ini adalah peningkatan kecerdasan kinestetik anak dalam pembelajaran seni pencak silat.

Instrumen yang digunakan untuk mengumpulkan data dalam penelitian ini yaitu lembar observasi dan dokumentasi. Analisis data yang digunakan meliputi (1) reduksi data, (2) display data, (3) verifikasi dan kesimpulan. Untuk mendapatkan data yang akurat perlu disusun suatu instrumen yang valid dan reliabel (Arikunto, dkk, 2006, hlm.127). Berdasarkan hal tersebut, maka validitas dan reliabilitas dalam penelitian ini meliputi triangulasi yang merupakan proses memastikan sesuatu (getting a fix) dari berbagai sudut pandang (Arikunto, dkk, 2006, hlm. 128) dan member checking yang merupakan pengecekan terhadap temuan-temuan dalam peneitian ini kepada partisipan untuk melihat apakah temuan tersebut akurat atau tidak.

\section{HASIL DAN PEMBAHASAN}

Pembelajaran dilakukan berdasarkan desain pembelajaran seni pencak silat yang terdapat pada Gambar 1. Indikator kecerdasan kinestetik yang menjadi penilaian terhadap anak meliputi (1) aspek lokomotor yaitu berjalan, (2) aspek non lokomotor yaitu meninju, mengayun, latihan keseimbangan dan gerakangerakan memutar tubuh, serta (3) aspek modifikasi yaitu gerakan-gerakan telapak tangan. Total jumlah item penilaian yaitu 13 item yang masing-masing item dinilai dengan pemberian skor skala 1-3, dimana skor 1 jika kurang, 2 jika cukup dan 3 jika baik. Penelitian ini dimulai dengan pengambilan data untuk keperluan data pra siklus. Tujuan dari observasi awal ini yaitu untuk mengetahui sejauh mana kecerdasan kinestetik yang dimiliki anak di PAUD GAMUS Bandung sebelum diterapkan pembelajaran seni pencak silat. Observasi awal ini dilakukan berdasarkan indikator kecerdasan kinestetik anak. Hasil pencapaian kecerdasan kinestetik anak pada pra siklus dapat dilihat dalam Diagram 1.

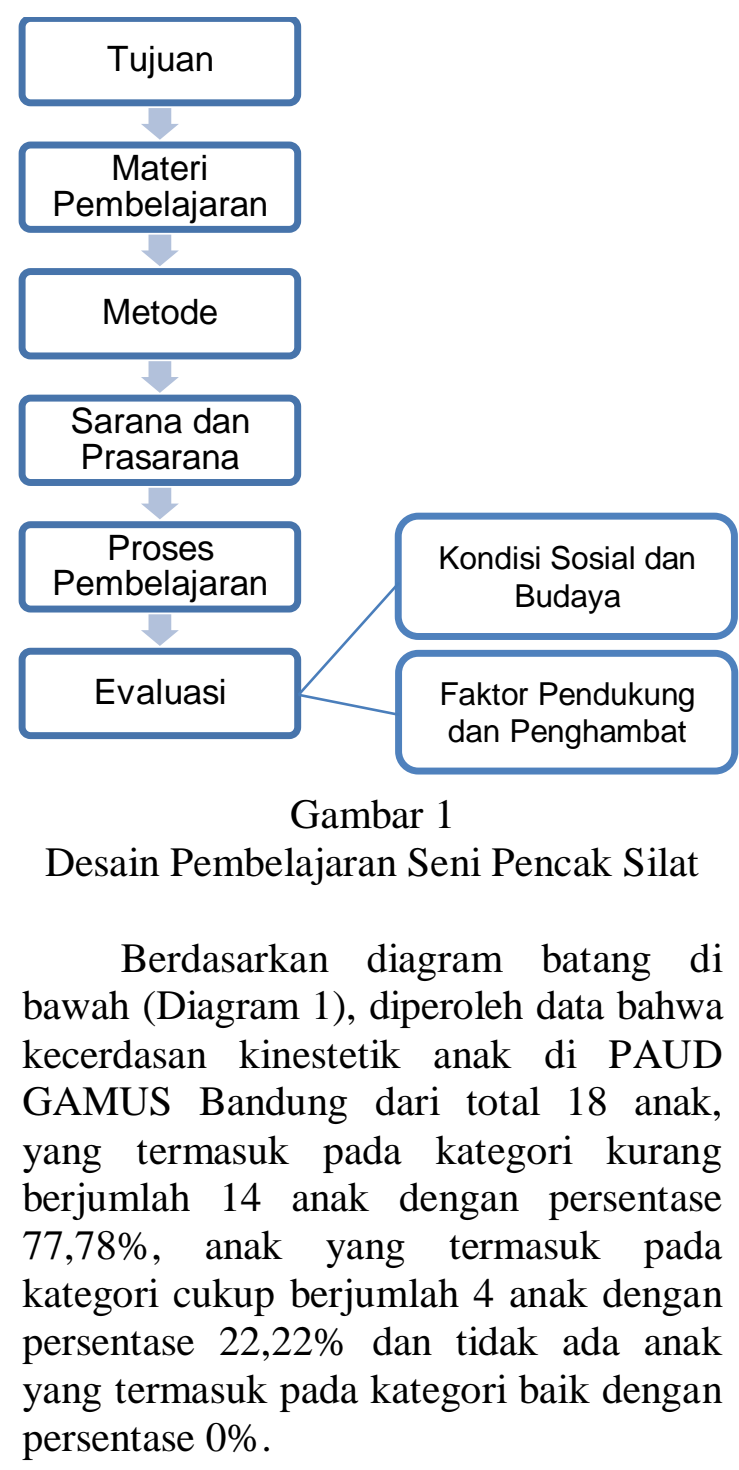




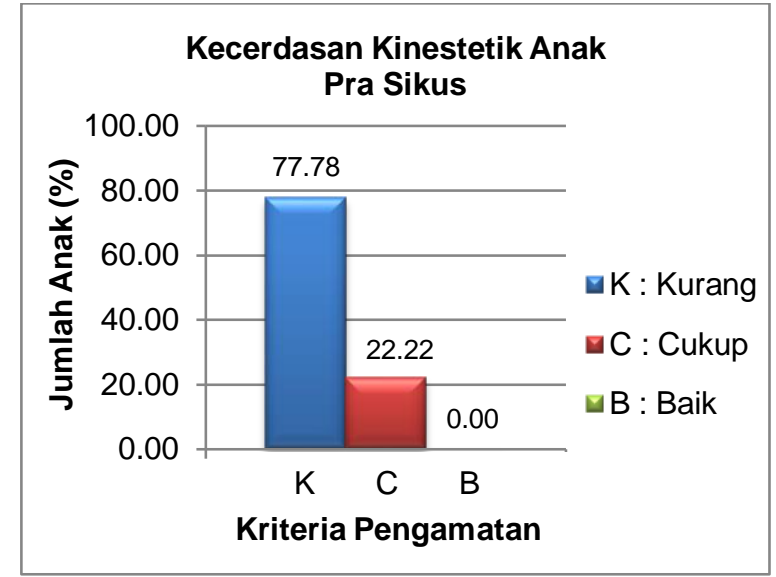

Diagram 1

Hasil Observasi Kecerdasan Kinestetik Anak pada Pra Siklus

Salah satu penyebab yang mengakibatkan kondisi kecerdasan kinestetik anak kurang baik sebelum diterapkannya pembelajaran seni pencak silat adalah pelaksanaan kegiatan pembelajaran yang masih bersifat konvensional, sehingga anak kurang aktif dalam bergerak. Guru jarang melakukan pembelajaran seni ketika di sekolah, guru hanya mengadakan pelatihan seni ketika terdapat acara-acara khusus yang membutuhkan anak untuk melakukan gerakan seperti menari dan sebagainya. Selain itu, kecerdasan kinestetik yang secara tidak langsung dilakukan oleh anak di sekolah hanya sebatas olah fisik sederhana seperti berlari mengejar temantemannya, melompat-lompat di ruang kelas dan menendang apa yang ada di depannya. Tidak terdapat pembelajaran khusus yang dilakukan guru untuk mengembangkan kecerdasan kinestetik anak. Siklus I

Siklus I terdiri dari tindakan I dan tindakan II. Hasil pencapaian kecerdasan kinestetik anak pada siklus I tindakan I dapat dilihat dalam Diagram 2 dan siklus I tindakan II dapat dilihat dalam Diagram 3.

Berdasarkan diagram batang di bawah (Diagram 2), diperoleh data bahwa kecerdasan kinestetik anak di PAUD GAMUS Bandung pada siklus I tindakan I dari total 18 anak, yang termasuk pada kategori kurang berjumlah 9 anak dengan persentase $50 \%$ begitupula anak yang termasuk pada kategori cukup berjumlah 9 anak dengan persentase 50\% dan tidak ada anak yang termasuk pada kategori baik dengan persentase $0 \%$.

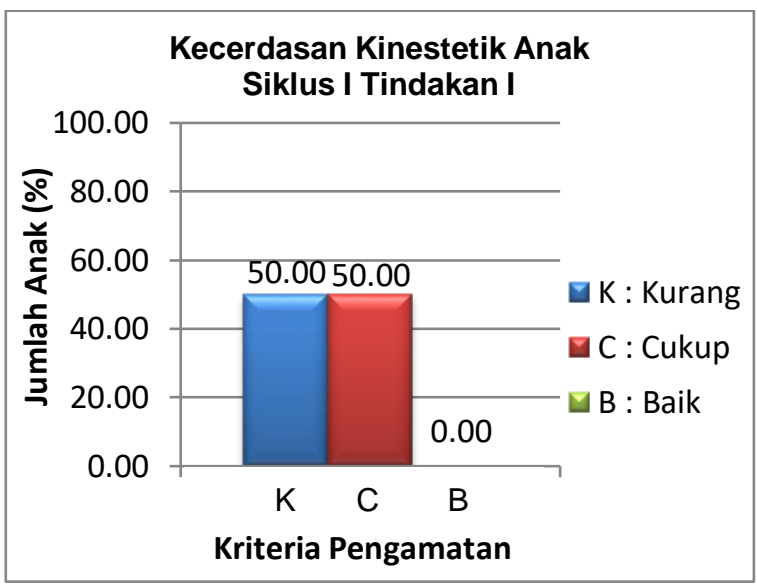

Diagram 2

Hasil Observasi Kecerdasan Kinestetik

Anak pada Siklus I Tindakan I

Pada tindakan I ini guru mencoba untuk tidak membagi anak ke dalam suatu kelompok. Hal ini dimaksudkan agar anak bebas dimana saja sesuai dengan keinginannya tidak terikat pada posisi yang ditentukan, namun hasilnya adalah observer kesulitan dalam melakukan penilaian apabila anak tidak dibagi ke dalam kelompok. Apalagi jumlah observer pada tindakan ini hanya satu orang. Dengan demikian, kegiatan pembelajaran seni pencak silat pada tindakan ini belum optimal. Hal tersebut ditunjukkan dengan masih banyaknya anak yang belum melakukan gerakan dengan baik. Selain itu, sebagian besar anak sulit untuk kondusif dalam mengikuti pembelajaran.

Berdasarkan diagram batang di bawah (Diagram 3), diperoleh data bahwa kecerdasan kinestetik anak di PAUD GAMUS Bandung pada siklus I tindakan II dari total 18 anak, yang termasuk pada kategori kurang berjumlah 6 anak dengan persentase $33,33 \%$, yang 
termasuk pada kategori cukup berjumlah 8 anak dengan persentase $44,44 \%$ dan yang termasuk pada kategori baik berjumlah 4 anak dengan persentase $22,22 \%$.

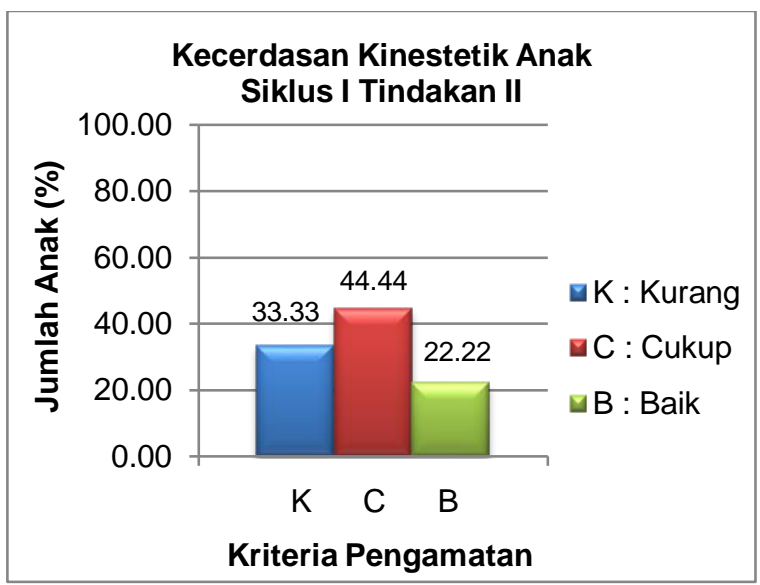

Diagram 3

Hasil Observasi Kecerdasan Kinestetik

Anak pada Siklus I Tindakan II

Pada tindakan ini, anak tetap tidak dibagi ke dalam kelompok karena jumlah observer sudah bertambah menjadi dua orang yang diharapkan dengan demikian dapat membantu mempermudah penilaian terhadap anak, namun hasilnya adalah walaupun satu observer mengamati setengah dari jumlah anak (9 anak), tetap saja pengamatan masih terlalu sulit apabila dilakukan secara bersamaan. Sementara itu, dengan membuat suasana yang menyenangkan anak sudah mulai tertarik untuk mengikuti pembelajaran sehingga anak dapat menjadi kondusif. Selain itu, dengan diadakannya kegiatan mewarnai gambar, dapat membantu anak dalam mengingat gerakan.

\section{Siklus II}

Siklus I terdiri dari tindakan I dan tindakan II. Hasil pencapaian kecerdasan kinestetik anak pada siklus II tindakan I dapat dilihat dalam Diagram 4 dan siklus II tindakan II dapat dilihat dalam Diagram 5.

Berdasarkan diagram batang di bawah (Diagram 4), diperoleh data bahwa kecerdasan kinestetik anak di PAUD GAMUS Bandung pada siklus II tindakan
I dari total 18 anak, yang termasuk pada kategori kurang berjumlah 3 anak dengan persentase $16,67 \%$, yang termasuk pada kategori cukup berjumlah 5 anak dengan persentase $27,78 \%$ dan yang termasuk pada kategori baik berjumlah 10 anak dengan persentase $55,56 \%$.

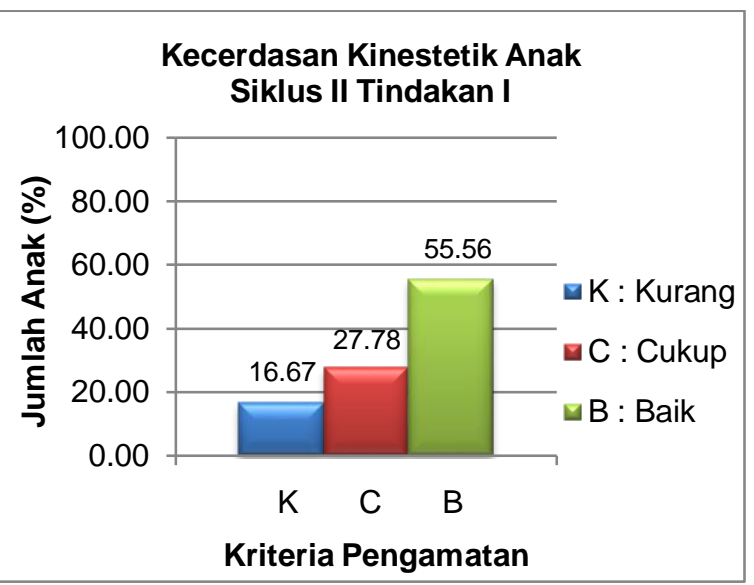

Diagram 4

Hasil Observasi Kecerdasan Kinestetik

Anak pada Siklus II Tindakan I

Pada tindakan ini, anak dibagi ke dalam 4 kelompok (masing-masing kelompok terdiri dari 4-5 anak). Dengan demikian, penilaian terhadap anak dapat lebih mudah dari sebelumnya, namun walaupun anak sudah dibagi ke dalam kelompok, tetap tidak dapat dipungkiri bahwa pengamatan lebih akurat apabila dilakukan terhadap masing-masing anak (satu per satu) secara bergiliran. Sementara itu, dengan dilakukannya penayangan video pencak silat, beberapa anak sudah cukup termotivasi untuk melakukan gerakan seni pencak silat.

Berdasarkan diagram batang di bawah (Diagram 5), diperoleh data bahwa kecerdasan kinestetik anak di PAUD GAMUS Bandung pada siklus II tindakan II dari total 18 anak, yang termasuk pada kategori kurang berjumlah 0 anak dengan persentase $0 \%$, yang termasuk pada kategori cukup berjumlah 3 anak dengan persentase 16,67\% dan yang termasuk pada kategori baik 
berjumlah 15 anak dengan persentase $83,33 \%$.

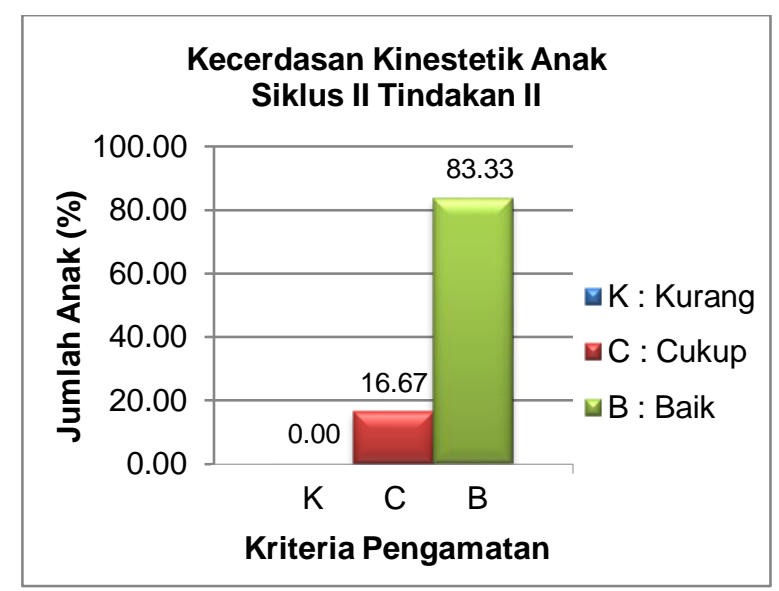

Diagram 5

Hasil Observasi Kecerdasan

Kinestetik Anak pada Siklus II Tindakan II

Pada tindakan ini, anak dibagi menjadi 8 kelompok (masing-masing kelompok terdiri dari 2 anak). Setiap kelompok melakukan gerakan seni pencak silat secara bergiliran, sehingga 1 observer hanya mengamati 1 anak. Dengan demikian, hasil pengamatan kecerdasan kinestetik anak dapat lebih akurat dan lebih mudah. Sementara itu, dengan digunakannya beberapa properti/ kostum seni pencak silat, dapat membuat anak menjadi lebih termotivasi dan lebih bersemangat dalam melakukan mengikuti pembelajaran.

Secara keseluruhan, peningkatan kecerdasan kinestetik anak melalui pembelajaran seni pencak silat ini dapat dilihat pada tabel berikut ini (Tabel 1). 
Tabel 1

Persentase Peningkatan Kecerdasan Kinestetik Anak

\begin{tabular}{|c|c|c|c|c|c|}
\hline \multirow{2}{*}{ Kategori } & \multicolumn{5}{|c|}{ Jumlah Anak (\%) } \\
\cline { 2 - 6 } & $\begin{array}{c}\text { Pra } \\
\text { Siklus }\end{array}$ & $\begin{array}{c}\text { Siklus I } \\
\text { Tindakan I }\end{array}$ & $\begin{array}{c}\text { Siklus I } \\
\text { Tindakan II }\end{array}$ & $\begin{array}{c}\text { Siklus II } \\
\text { Tindakan I }\end{array}$ & $\begin{array}{c}\text { Siklus II } \\
\text { Tindakan II }\end{array}$ \\
\hline $\begin{array}{c}\text { Kurang } \\
\text { (K) }\end{array}$ & 77,78 & 50,00 & 33,33 & 16,67 & 0,00 \\
\hline $\begin{array}{c}\text { Cukup } \\
\text { (C) }\end{array}$ & 22,22 & 50,00 & 44,44 & 27,78 & 16,67 \\
\hline $\begin{array}{c}\text { Baik } \\
\text { (B) }\end{array}$ & 0,00 & 0,00 & 22,22 & 55,56 & 83,33 \\
\hline
\end{tabular}

Berdasarkan pengamatan pada observasi awal (pra siklus), rata-rata kecerdasan kinestetik di PAUD GAMUS Bandung masih berada pada kategori kurang. Akan tetapi, setelah diterapkannya pembelajaran seni pencak silat secara bertahap kecerdasan kinestetik anak mengalami pengingkatan. Sehingga dapat disimpulkan bahwa setelah diterapkannya pembelajaran seni pencak silat pada anak di PAUD GAMUS Bandung, kecerdasan kinestetik anak mengalami peningkatan yang signifikan.

Hal ini dapat dilihat dari dari 18 anak, pada pra siklus yang termasuk pada kategori kurang (K) berjumlah 14 anak dengan persentase $77,78 \%$ menurun pada siklus I tindakan I menjadi 9 anak dengan persentase $50,00 \%$, kemudian menurun lagi pada siklus I tindakan II menjadi 6 anak dengan persentase $33,33 \%$, lalu kembali menurun pada pada siklus II tindakan I menjadi 3 anak dengan persentase $16,67 \%$, dan pada akhir siklus menurun menjadi tidak terdapat anak yang termasuk pada kategori tersebut. Selanjutnya dari 18 anak, pada pra siklus yang termasuk pada kategori cukup (C) berjumlah 4 anak dengan persentase $22,22 \%$, lalu pada siklus I tindakan I menjadi 9 anak tetapi dengan persentase yang menurun yaitu $50,00 \%$, kemudian menurun lagi pada siklus I tindakan II menjadi 8 anak dengan persentase $44,44 \%$, dan kembali menurun pada pada siklus II tindakan I menjadi 5 anak dengan persentase $27,78 \%$, hingga pada akhir siklus menurun menjadi 3 anak dengan persentase $16,67 \%$. Selanjutnya dari 18 anak, baik pada pra siklus maupun pada siklus I tindakan yang termasuk pada kategori baik (B) berjumlah 0 anak dengan persentase $0,00 \%$, lalu pada siklus I tindakan II meningkat menjadi 4 anak dengan persentase $22,22 \%$, dan kembali meningkat pada pada siklus II tindakan I menjadi 10 anak dengan persentase $55,56 \%$, hingga pada akhir siklus meningkat menjadi 13 anak dengan persentase $83,33 \%$.

\section{KESIMPULAN}

Berdasarkan hasil penelitian mengenai peningkatan kecerdasan kinestetik melalui pembelajaran seni pencak silat yang dilaksanakan di PAUD GAMUS Bandung, maka dapat disimpulkan bahwa :

1. Kondisi objektif kecerdasan kinestetik anak di PAUD GAMUS Bandung masih perlu perhatian yang lebih lagi, mengingat hasil observasi sebelum diberikannya tindakan yaitu rata-rata anak memiliki kecerdasan kinestetik pada kategori kurang, bahkan belum terdapat anak yang memiliki kecerdasan kinestetik pada kategori baik.

2. Pelaksanaan pembelajaran seni pencak silat memberikan dampak positif bagi anak dilihat dari hasil pengamatan di setiap pergantian siklus yang terus mengalami peningkatan. Pada siklus I tindakan I telah terlihat adanya 
peningkatan dalam kecerdasan kinestetik anak. Pada siklus I tindakan II anak terlihat lebih antusias dari sebelumnya, sehingga kecerdasan kinestetik anak pun lebih berkembang. Pada siklus II tindakan I kecerdasan kinestetik anak semakin berkembang denga baik. Pada siklus II tindakan II, kecerdasan kinestetik anak secera keseluruhan sudah mengalami peningkatan yang cukup baik. Apalagi dengan digunakannya properti seni pencak silat, anak semakin bersemangat dalam mengikuti pembelajaran.

3. Peningkatan kecerdasan kinestetik anak di PAUD GAMUS Bandung setelah diterapkannya pembelajaran seni pencak silat mengalami peningkatan yang signifikan. Perolehan rata-rata kecerdasan kinestetik meningkat dan hampir semua anak dalam kategori baik dan sudah tidak terdapat anak dalam kategori kurang. Kegiatan pembelajaran seni pencak silat untuk meningkatkan kecerdasan kinestetik anak dapat berjalan dengan baik dan sesuai yang diharapkan.

\section{REFERENSI}

Arikunto, Suharsimi dkk. 2006. Penelitian Tindakan Kelas. Jakarta : PT Bumi Aksara.

Aryaprastya, I Gusti Komang. 2015. Implementasi Kecerdasan Kinestetik Anak Usia Dini Melalui Pembelajaran Tari Anak Nusantara. 6th Pedagogy
International Seminar 2015. The

Development of Pedagogical

Education From The Perspective Of

The 21st Century And Cooperation Asean Educator Community. ISSBN 978-979-3786-50-6. UPI Press : hlm.1321-1328.

Kriswanto, Erwin Setyo. 2008. Model Pembelajaran dan Prinsip Bermain Pencak Silat untuk Anak Pra Sekolah. Jurnal Pendidikan Jasmani Indonesia. 3 (3), hlm. 70-78.

Maryono, O'ong. 2000. Pencak Silat Merentang Waktu. Yogyakarta : Galang Press.

Natassia, Naomi dkk. 2015. Penciptaan Buku Ilustrasi Pencak Silat untuk Anak-anak Usia 6-9 Tahun sebagai Upaya Pengenalan Warisan Budaya Bangsa. Jurnal Desain Komunikasi Visual. 4 (2), hlm. 1-10.

Sujiono, Yuliani Nurani dan Sujono, Bambang. 2010. Bermain Kreatif Berbasis Kecerdasan Jamak. Jakarta : PT. Indeks.

Suyadi, dan Maulidya Ulfah. 2013. Konsep Dasar PAUD. Bandung : Rosdakarya.

Yaumi, Muhammad dan Nurdin Ibrahim. 2013. Pembelajaran Berbasis Kecerdasan Jamak. Jakarta : Kencana Prenada Media Grup 
